\title{
Evaluation of Intercropping Legume Covers with Maize on Soil Moisture Improvement in Misrak Azerinet Berbere woreda, SNNPR, Ethiopia
}

\author{
Bagegnehu Bekele ${ }^{1}\left[\right.$ D $\cdot$ Dagnaw Ademe ${ }^{1} \cdot$ Yenealem Gemi $^{1} \cdot$ Temesgen Habtemariam $^{1}$
}

Received: 20 February 2021 / Revised: 4 June 2021 / Accepted: 15 June 2021 / Published online: 25 June 2021

(C) The Author(s) 2021

\begin{abstract}
In Ethiopia, particularly Southern Regional State dry land crop productivity is majorly influenced by low soil moisture stress. The current study has been conducted to evaluate the effect of intercropping maize with legumes covers on Soil Moisture improvement at Misrak Azerinet Berbere woreda. Seven treatments evaluated were vetch with maize, lablab with maize, vetch only, lablab only, and maize only. The experimental design was in a randomized complete block design (RCBD) with three replications in a permanent plot. Disturbed soil samples were collected from the intra-row spacing from both intercropped and non-intercropped plots from the depth of 0-20 cm and composited for soil moisture analysis. The yield and biomass of maize and legume shrubs have been collected. The Land Equivalent Ratio (LER) was computed to evaluate the land productivity of intercropped combinations. The result reveals that in both years, yield, biomass, and soil moisture content were not significant $(p>0.05)$ at a statistically significant level. After crop harvest, maize with lablab has better soil moisture relative to other combinations (first year). In both years, the soil moisture content in the soil was reduced in the sole crop of maize compared with sole vetch. However, the soil moisture content in the soil was increased in maize intercropped with lablab in both development stage and after harvest compared with maize intercropped with vetch. Both legume shrubs under mono and intercropped conditions conserve soil moisture relative to maize under mono cropped conditions. This implies the benefit of legume shrubs on soil moisture conservation both planted under mono cropped conditions and intercropped conditions. It is concluded that the combination of intercropping maize with legume shrubs could substantially increase soil moisture conservation and improve the overall land productivity. Therefore, for maximum maize production, farmers in the area should plant maize with a combination of vetch and lablab. Additionally, farmers should practice double cropping with the residual soil moisture from legume and its combinations.
\end{abstract}

Keywords Soil moisture conservation $\cdot$ Maize $\cdot$ Lablab $\cdot$ Vetch $\cdot$ Land equivalent ratio

\section{Background}

Rising temperatures, associated with the low rainfall distribution, have a direct negative effect on vegetation cover, which in turn contributes to soil degradation because of the exposure of the soil surface to wind and water erosion. According to Setegn et al. (2009), as cited by Bekele and Gemi [1], the causes for land degradation

Bagegnehu Bekele

bagegnehubekele@gmail.com

1 Soil and Water Conservation Research, Worabe Agricultural Research Center, Southern Agricultural Research Institute, P.O.BOX 21, Worabe, Ethiopia in Ethiopia are lack of effective watershed management system and poor land use practices, and unwise management and the use of natural resources are also the major challenges affecting crop yield in the Southern region [2]. Bekele et al. [3] reported the gross erosion from the Karesa watershed as 42,413.72 ton $_{\text {year }}{ }^{-1}$,Bekele [4] reported the soil erosion from Berta watershed south-central rift valley Basin of Ethiopia as 81,864 ton year ${ }^{-1}$,Bekele and Gemi [1] reported the gross soil erosion from Dijo watershed in south-central rift valley basin of Ethiopia as 456,415.60 tons/year. This indicates the spatial variability of soil erosion due to the variability of rainfall, soil, topographic, and management factors. Such variability calls to mitigate soil erosion through improved soil and water conservation measures. 
Intercropping of cereals and legumes is important for the development of sustainable food production systems, particularly in cropping systems with limited external inputs and fragmented land distribution. Many studies confirmed the magnificent benefits of intercropping of cover legumes over sole cropping. High productivity and profitability, improvement of soil fertility, efficient use of resources, reducing damage caused by pests, diseases, and weeds (Javanmard et al. 2009) are some of the benefits concluded after study. Different studies verified that cover legumes such as lablab, cowpea, and vetch are highly effective in this regard ( [5]. When combined with conservation tillage, in (Lidia et al. 2004), it is indicated that the contribution of cover legumes in improving soil quality, moisture-holding capacity, weed suppression, and crop yield is many fold.

In addition, due to their cover nature, these legumes are also highly effective in conserving soil moisture and reducing soil erosion. However, this important aspect of the legumes is usually bypassed and more focus is being given to their contribution to soil nutrients balance. When intercropped with maize, it is verified that cover legumes such as cowpea (Clark et al. 1997 and [6], lablab (Janet et al.2014), and vetch [7] could significantly contribute to soil moisture conservation and increased soil productivity compared to sole maize cropping.

In dry lands and moisture stress areas, usually crop failure due to moisture shortage in soils is very much common. There is high evaporation of water out of soil due to increased temperature. Sometimes farmers try to cope up with this problem by using mulches of crop residues, but this is also highly challenged because the crop residues are used as feed for animals. Therefore, using the advantage and opportunity of covering legumes as an intercrop in moisture stress areas solve the problems simultaneously in addition to their contribution improving soil nutrient balance and other many fold benefits. The effect of Intercropping and its spatial arrangement of legume shrubs (vetch or lablab) grown in association with maize in the southern region particularly in the study area has not been extensively studied and not well documented.

Therefore, this study has been conducted to evaluate the effect of different legume covers (vetch and lablab) intercropping with maize in soil moisture conservation and crop yield in moisture stress areas of SNNPR.

\section{Materials and Methods}

\section{Study Area Description}

The experiment was conducted in Misrak azerinet Berbere woreda on a farmer's field for two consecutive years (2010/11-2011/120. The experimental site was situated at $37^{\circ} 59^{\prime} 30^{\prime \prime} \mathrm{E}$ to $38^{\circ} 1^{\prime} 30^{\prime \prime} \mathrm{E}$ longitude and $7^{\circ} 41^{\prime} 30^{\prime \prime} \mathrm{N}$ to $7^{\circ} 45^{\prime} 0^{\prime \prime} \mathrm{N}$ latitude with an altitude range of 1988 to 2190 masl.

The soil is lithosols with sandy clay soil textural characteristics (32\% sand, $48 \%$ clay, and $20 \%$ silt). The soil leads almost moderate acidic $\mathrm{pH}$ (4.58) with $1.36 \mathrm{ds} / \mathrm{m} \mathrm{EC,} 1.28 \%$ OC, $2.2 \% \mathrm{OM}, 13 \mathrm{ppm} \mathrm{P}, 86 \mathrm{ppm} \mathrm{K}, 0.11 \%$ of TN.

\section{Experimental Design}

The treatments evaluated were vetch with maize, lablab with maize, vetch only, lablab only, and maize only. The experimental design was in a randomized complete block design (RCBD) with seven treatments replicated three times in a permanent plot. The numbers of the total experimental plot were 15. Each plot had an area of $20 \mathrm{~m}^{2}$. Damot maize variety was used and spaced at $30 \mathrm{~cm}$ apart, with $80 \mathrm{~cm}$ between rows. Lablab was spaced at $30 \mathrm{~cm}$ apart and vetch was planted through drilling methods. Legume shrubs were planted in single row in between rows of maize.

NPS fertilizer at the rate of $121 \mathrm{~kg}$ NPS $\left(23 \mathrm{~N}-46 \mathrm{p}_{2} \mathrm{O}_{5^{-}}\right.$ $7 \mathrm{~S})+100 \mathrm{~kg} / \mathrm{ha}$ urea site recommended fertilizer was added. Urea was applied at two split one-third during planting and two-third at 45 days after planting. Maize recommended fertilizer was used for each legume shrubs. The recommended seeding rate of vetch $15 \mathrm{~kg} / \mathrm{ha}$ and $30 \mathrm{~kg} / \mathrm{ha}$ of both lablab and cowpea was used. All legume shrubs planted simultaneously with maize.

\section{Soil Moisture Content}

To monitor the soil moisture status of each plot, disturbed soil samples were collected from the intra-row spacing of maize and each legume covers from three different points at $20 \mathrm{~cm}$ soil depth. Similarly, for non-intercropped plots, soil samples were collected from the intra-row spacing from three different points and composited. The soil sample was collected at planting, flowering, and after harvest. The date of the sampling was at 3 to 5 days after rain; if the rainfall interval allows, it is recommended to sample at 5 days after rainfall. Finally, a sample of $1 \mathrm{~kg}$ was taken to the laboratory and oven-dried at $105{ }^{\circ} \mathrm{C}$ room temperature and the soil moisture contents were determined using gravimetric methods by using the following formula (RNAM, 1995)

$\mathrm{SMC}=\frac{\mathrm{Ww}-\mathrm{Wd}}{\mathrm{Wd}} \times 100$

where SMC, soil moisture contents \%; Ww, weight of wet soil (gm); Wd, weight of dry soil (gm).

In addition, representative composite soil samples were collected before the experiment from 20-30 spots to make one composite sample, following the standard soil sampling 
procedure. Similarly, plot-based soil samples were collected after crop harvest for physico-chemical analysis.

\section{Yield of Maize and Legume Shrubs}

At harvest (after 120 days from planting), the middle four rows of each plot $\left(16 \mathrm{~m}^{2}\right)$ were harvested from maize and legume shrubs to determine yield and biomass (kg/plot) and were converted to hectare $\left(10,000 \mathrm{~m}^{2}\right)$ to determine the productivity in $\mathrm{kg} / \mathrm{ha}$. Land Equivalent Ratio.

Land equivalent ratio (LER) determined as the sum of the two fractions of the yield of the intercrops relative to their sole crop yields according to the following formula [8]:

LER $=\frac{\text { YMint }}{\text { YMsol }}+\frac{\text { YLint }}{\text { YLsol }}$

where YMint, yield of maize under intercropping conditions; YMsol, yield of maize under sole crop conditions; YLint, yield of legume under intercropping conditions; YLsol, yield of legume under sole crop conditions.

\section{Data Analysis}

The collected data has been analyzed using simple descriptive statistics. In addition, some of the collected data were subjected to the analysis of variance procedures and LSD multiple comparison test.

\section{Result}

\section{Effect of Intercropping on Soil Moisture Conservation}

The result on soil moisture conservation reveals that at development stage, sole vetches have better soil moisture relative to other combinations. Maize with vetch and maize with lablab have comparable soil moisture at this stage in the first year (Fig. 1). In the second year, at development stage, sole vetch conserves moisture relative to sol lablab and sol maize whereas maize with lablab conserves soil moisture relative to maize with vetch. After crop harvest, maize with lablab has better soil moisture relative to other combinations (first year). In both years, the soil moisture content in the soil was reduced in the sole crop of maize compared with sole vetch.

The result of soil moisture content in a 2-year period is low. This could be due to the characteristics of the sandy clay texture of the soil, which has low water holding capacity. Although soil moisture is low, both legume shrubs under mono and intercropped condition conserve soil moisture relative to maize under mono cropped condition. Comparatively, the trend of soil moisture content at different stages in 2018/2019 is by far higher than the cropping season of $2019 / 2020$. This could be due to the rainfall distribution in the area.

\section{Effect on Intercrop Yield}

In both years, statistically, there were no significant yield and biomass differences in between legume shrubs and maize. The yield of both maize and legume intercrops was reduced relative to mono cropped condition (Tables 1, 2, 3, and 4).

\section{Land Use Efficiency by the Intercrops}

The effect of intercropping on land use efficiency was evaluated on the basis of land equivalent ratio (LER). Based on the result, the land equivalent ratio was recorded higher in both vetch and lablab intercropped combinations relative to pure stand yield of maize. In both cropping season, the land equivalent ratio under the plot treated by intercropping is higher compared to the pure stand plot. In first year, the LER values for maize with vetch and lablab are 1.45 and 1.1 respectively (Table 2 ) above. This indicates that $45 \%$ and $10 \%$ more area would be required by sole cropping system to equal the yield of the intercropping pattern, whereas in the second year, LER values for maize with vetch and lablab are 1.55 and 1.56 respectively (Table 4 ) below which indicates that $55 \%$ and $56 \%$ more area would be required by sole cropping system to equal the yield of the intercropping pattern (Table 3). The result table shows, land equivalent ratio are in general was higher if maize intercropped with vetch and lablab. (Table 5)

The land equivalent ratio shows greater than 1 which shows the advantages of intercropping compared when each component was grown alone.

\section{Discussion}

The current study evaluated the effect of intercropping maize with legume shrubs on land productivity and soil moisture content. According to the result (Fig. 2), the soil moisture content in the soil was increased in maize intercropped with lablab in both development stage and after harvest compared with maize intercropped with vetch. This shows the benefit of legume shrubs on soil moisture conservation both planted at mono cropped condition and intercropped condition. The finding is in line with Janet et al. (2014), and Sainju and Sing [7], the significant contribution of both lablab and vetch on soil moisture conservation and increased soil productivity compared to the sole maize cropping system, respectively. Similarly, the finding by Dahmardeh and Rigi [9] confirms the significantly higher soil moisture content of maize legume intercropped condition relative to mono 


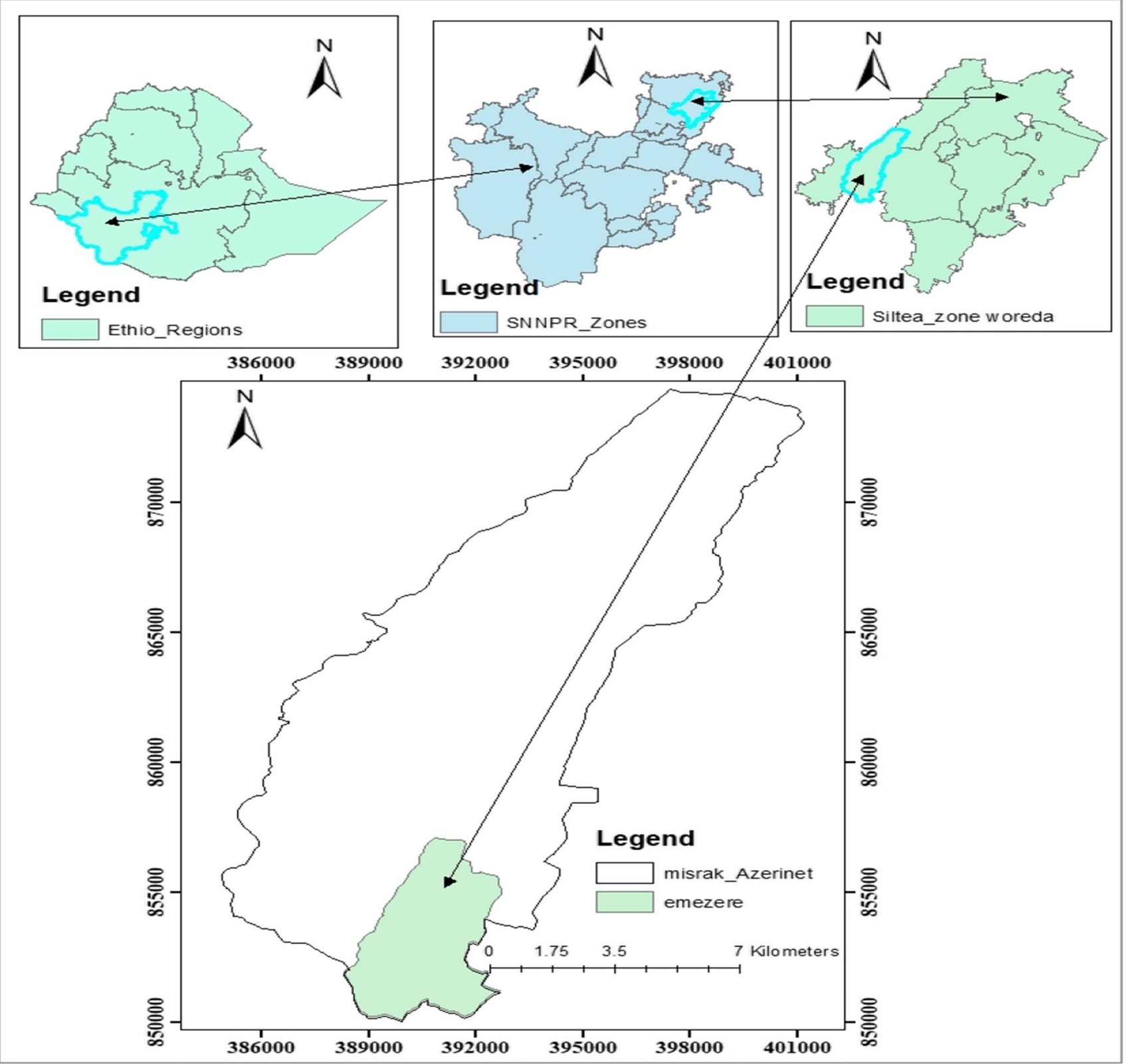

Fig. 1 Location map

Table 1 Effect of intercropping maize with legume on yield and LER (2018/2019)

\begin{tabular}{lcccl}
\hline Treatment & \multicolumn{4}{l}{ Grain yield(kg/ha) } \\
\cline { 2 - 5 } & Maize & Vetch & Lablab & LER \\
\hline Maize + vetch & 3777.8 & 1139 & - & 1.45 \\
Maize + lablab & 3305.5 & - & 944.4 & 1.1 \\
Maize only & 4777.8 & - & - & 1 \\
Vetch only & - & 1722 & - & 1 \\
Lablab only & - & - & 2291.6 & - \\
\hline
\end{tabular}

Table 2 Maize yield and biomass under legume shrubs (2019/2020)

\begin{tabular}{lll}
\hline Treatments & Yield(kg/ha) & Biomass(kg/ha) \\
\hline Maize only & 3050.0 & 7750.0 \\
Maize with vetch & 2900.0 & 7250.0 \\
Maize with lablab & 2700.0 & 6625.0 \\
Mean & 2883.3 & 7208.3 \\
LSD $(0.05 \%)$ & $\mathrm{NS}$ & $\mathrm{NS}$ \\
CV $(\%)$ & 9.2 & 10.2 \\
\hline
\end{tabular}

*Means with the same letter is not statistically different at 5\% significance level. 
Table 3 Grain yield and biomass of lablab (2019/2020)

\begin{tabular}{lll}
\hline Treatments & Gyld (kg/ha) & Bms (kg/ha) \\
\hline Maize with lablab & 1200.0 & 3208.3 \\
Sole Lablab & 1750.0 & 5716.7 \\
Mean & 1475.0 & 4462.5 \\
CV $(\%)$ & 23.1 & 22.2 \\
LSD $(0.05 \%)$ & NS & NS \\
\hline
\end{tabular}

*Means with the same letter is not statistically different at $5 \%$ significance level.

Gyld grain yield, Bms biomass

cropped condition due to high evaporation potential in the sole maize. However, the grain yield of both maize and legume shrubs under mono cropped condition is lower than intercropped condition. Ayele [10] evaluated that the soil moisture content in the sole crop of maize decreased due to high evapotranspiration potential and increased in the sole crop of cowpea. The reduction on grain yield on legumes shrubs could be due to the shading effect of maize which probably due to the receipt of lower amount of incoming solar radiation which affected the rate of photosynthesis and thereby translocation of photosynthesis from source to sink. The lower grain yield in both maize and legume sol condition could be compensated by the total productivity from the entire plot of land. According to Patra et al. (2000), maize in association with legumes gives higher total yield and net return. In both years, since there were no statistically significant maize yield differences $(p>0.05)$ observed, separate year result was reported. However, in both years, the sole maize yield was higher than intercrop maize yield. The report of Ertürk [11] and Sabanc1 [12] confirmed that the grain yield of sole maize yield was higher than intercrop maize yield. The land efficiency of intercrop also evaluated in terms of land equivalent ratio (LER). In both cropping seasons, the LER $>1$ (Tables 1 and 4 ), which shows the benefits of intercropping. The land equivalent ratio in the second year is greater than the first year cropping season, which could be due to the favorable climatic condition in
Table. 5 Land equivalent ratio of intercropping (2019/2020)

\begin{tabular}{lllll}
\hline Grain yield kg/ha & & & LER \\
\hline Treatments & Maize & Vetch & Lablab & \\
\hline Maize with vetch & 2900 & 1437.5 & - & 1.55 \\
Maize with lablab & 2700 & - & 1200 & 1.56 \\
Vetch only & - & 2375 & - & 1 \\
Lablab only & & - & 1750 & 1 \\
Maize only & 3050 & - & - & 1 \\
\hline
\end{tabular}

LER land equivalent ratio.

the area. According to the finding of Izaurralde et al. (1994), the LER value greater than 1 implies more efficient utilization of land by intercrops compared to growing monocrop in the farms. The result is consistent with the finding of [13], which reported the LER of both maize and legume combinations as 1.5. The finding of Gebremichael et al. [14] also reported the positive advantage of intercropping sorghum with cowpea (LER $>1$ ) while intercropping sorghum with pigeon pea negatively affects crop productivity. The finding of Ayele [10] also reported land equivalent ratio (LER) for the grain yield of maize and lablab was 1.7 , while 1.9 LER was obtained from the intercropping of maize with cowpea. The finding of Gebremichael et al. [14] confirmed that intercropping sorghum with pigeon pea and cowpea increases the land productivity as its land equivalent ratio is greater than 1 . This implies intercropping legume shrubs with maize improve the land use efficiency. The result also revealed that yield advantages from maize intercropped with legumes (lablab and vetch) compared to maize sole cropping due to better land advantages and better total use of available resources. The finding of Mahapatra [15] and Valdez and Fransen [16] confirmed the advantages of intercropping in the crop production in comparison with pure cropping are due to the interaction between components in intercrops and the difference in competition for the use of environmental resources. This implies increasing the efficiency of agricultural land use could improve the quality of the environment by improving the quality of soil, water, and crops (Fig. 3).
Table 4 Grain yield and biomass of vetch (2019/2020)

\begin{tabular}{lll}
\hline Treatments & Gyld $(\mathrm{kg} / \mathrm{ha})$ & Bms $(\mathrm{kg} / \mathrm{ha})$ \\
\hline Maize with vetch & 1437.5 & 4125 \\
Sole vetch & 2375.0 & 12,167 \\
Mean & 1906.2 & 8145.8 \\
CV $(\%)$ & 24.1 & 26.8 \\
LSD $(0.05 \%)$ & $\mathrm{NS}$ & $\mathrm{NS}$ \\
\hline
\end{tabular}

*Means with the same letter is not statistically different at $5 \%$ significance level.

Gyld grain yield, Bms biomass

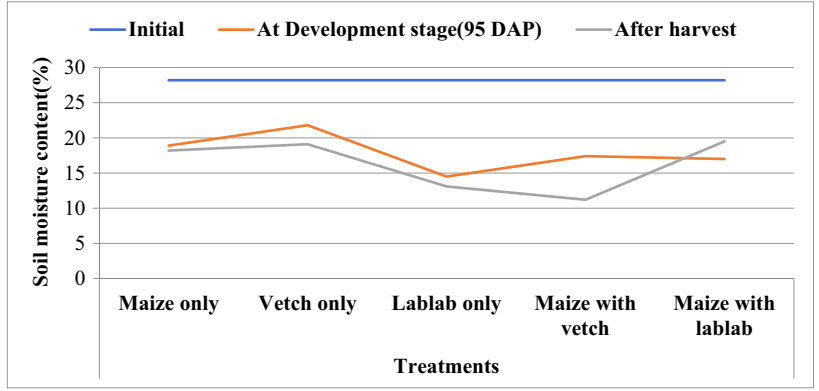

Fig. 2 Soil moisture content in 2018/2019. DAP, days after planting 


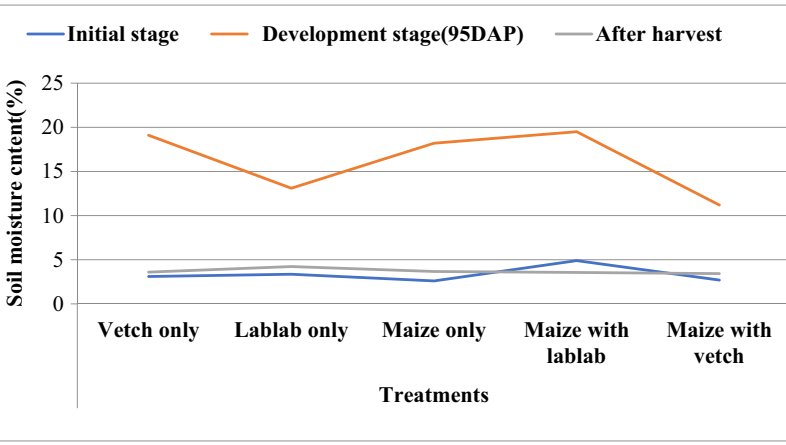

Fig. 3 Soil moisture content in 2019/2020. DAP, days after planting

In general, many researchers agree that intercropping maize with legume shrubs could substantially improve the soil moisture contents and reduce soil erosion, improving soil fertility and land productivity. According to Shetty et al. [17], the main reason of farmers intercrop is due to their flexibility, profit maximization, risk minimization against total crop failure, soil conservation, and improvement of soil fertility, weed control, and balanced nutrition.

\section{Conclusion and Recommendation}

Intercropping tested in this study could be an option to improve maize yield. The combination of intercropping maize with legume shrubs could substantially increase soil moisture content. The tested combinations of intercropping also improve the overall land productivity. Therefore, for maximum maize production, farmers in the area should plant maize with combination of vetch and lablab. Farmers should practice double cropping with the residual soil moisture from legume and its combinations. Additionally, the effect of intercropping legume with maize and the crop types on soil erosion and soil fertility improvement should be studied.

Supplementary Information The online version contains supplementary material available at https://doi.org/10.1007/s41101-021-00109-w.

Acknowledgements The authors thank Worabe Agricultural Research Centre for facilitating field resources required to complete the experiment. Our appreciation also goes to Natural resource management research directorate field and technical assistant for their contribution in collecting field data.

Author Contribution BB has led overall research activities from proposal development to data compilation, data entry and processing, data analysis, and interpretation of the result and writing up full manuscript. DA and TH have involved in collecting field data. YG has involved in data coding, checking, and comments on output manuscript.
Funding This study has received limited financial support from the Agricultural Growth Program (AGP).

Data Availability The required data collected for analysis are included in the manuscript. The corresponding author is ready to clarify the data and provides all the necessary data set as per the request.

\section{Declarations}

Consent for Publication We all have agreed on data in the manuscript and submit our final manuscript to journal of water conservation science and engineering for approved.

Competing Interests The authors declare no competing interests.

Open Access This article is licensed under a Creative Commons Attribution 4.0 International License, which permits use, sharing, adaptation, distribution and reproduction in any medium or format, as long as you give appropriate credit to the original author(s) and the source, provide a link to the Creative Commons licence, and indicate if changes were made. The images or other third party material in this article are included in the article's Creative Commons licence, unless indicated otherwise in a credit line to the material. If material is not included in the article's Creative Commons licence and your intended use is not permitted by statutory regulation or exceeds the permitted use, you will need to obtain permission directly from the copyright holder. To view a copy of this licence, visit http://creativecommons.org/licenses/by/4.0/.

\section{References}

1. Bekele B, Gemi Y (2021) Soil erosion risk and sediment yield assessment with universal soil loss equation and GIS: in Dijo watershed, Rift valley Basin of Ethiopia. Model. Earth Syst. Environ 7(1):273-291. https://doi.org/10.1007/s40808-020-01017-z

2. Tsegaye G, Gebremichael A (2014) Review on overall status of soil and water conservation system and its constraints in diferent agro ecology of southern Ethiopia. J Nat Sci Res 4(7):59-69

3. Bekele B, Muluneh A, Wondrade N (2019) Geographic Information System (GIS) based soil loss estimation using Universal Soil Loss Equation Model (USLE) for soil conservation planning in Karesa Watershed, Dawuro Zone, and South West Ethiopia. Int J Water Resour Environ Eng 11(8):143-158. https://doi.org/10. 5897/IJWREE2018.0820

4. Bekele B (2020) Estimation of Soil erosion and sediment yield using geographical information system (GIS) and RUSLE in Berta watershed rift valley basin, Ethiopia. Global Journal of Science Frontier Research: D Agriculture and Veterinary (Article under press)

5. Lemlem A (2013) The effect of intercropping maize with cowpea and lablab on crop yield. Herald Journal of Agriculture and Food Science Research 2(5):156-170

6. Bayer C, Mielniczuk J, Amado TJC, Martin-Neto L, Fernandes SV (2000) Organic matter storage in a sandy clay loam Acrisol affected by tillage and cropping systems in southern Brazil. Soil Tillage Res 54:101-109

7. Sainju and Sing (1997) Tillage and cover crop effects on maize yield and soil abstract.

8. Willey, R. (1979a). Intercropping-its importance and research needs: Part 1. Competition and yield advantages. In Field crop abstracts (Vol. 32, pp. 1-10). 
9. Dahmardeh M, Rigi K (2013) The Influence of Intercropping Maize (Zea mays L.) Green Gram (Vigna Radiata L.) on the Changes of Soil Temperature, Moisture and Nitrogen. Int J Ecosys 3(2):13-17. https://doi.org/10.5923/j.ije.20130302.01

10. Ayele HM (2020) Evaluation of the effect of maize-legume intercropping on soil moisture improvement in arid area of BenaTsemay district, South omo zone, Southern Ethiopia. Int J Agril Res Innov Tech 10(1):80-86. https://doi.org/10.3329/ijarit.v10i1. 48097

11. Ertürk, E., 2011. Misır (Zea mays L.) /Baklagil Birlikte Ekim Sisteminde Baklagillerin Mısır Bitkisinin Verim ve Verim Öğelerine Etkisi. Ordu Üniversitesi, Fen Bilimleri Enstitüsü, Tarla Bitkileri Anabilim Dalı, Yüksek Lisans Tezi, Ordu, 35 p.

12. Sabanc1, İ., 2015. Mısır-Soya Birlikte Üretim Şekillerinin Bazı Agronomik Özelliklere Etkisi. Adnan Menderes Üniversitesi, Fen Bilimleri Enstitüsü, Tarla Bitkileri Anabilim Dalı Doktora Tezi, Aydin, $101 \mathrm{p}$.

13. Amede T, Nigatu Y (2001) Interaction of components of sweet potato-maize intercropping under the semi-arid conditions of the Rift-Valley. Ethiopia Trop Agric 78:1-7

14. Gebremichael A, Bekele B, Tadesse B (2019) Evaluation of the effect of sorghumlegume intercropping and its residual effect on yield of sorghum in yekiworeda, sheka zone. Ethiopia Int J Agril Res Innov Tech 9(2):62-66. https://doi.org/10.3329/ijarit.v9i2. 45412

15. Mahapatra SC (2011) Study of grass-legume intercropping system in terms of competition indices and monetary advantage index under acid lateritic soil of India. American Journal of Experimental Agriculture 1(1):1-6

16. Valdez FR, Fransen SC (1986) Corn- sunflower intercropping as silage crop. J Dairy Sci 69:138-142

17. Shetty, S. V. R., Ntare, B. R., Bationo, A., Renard, C (1995) Millet and Cowpea in Mixed Farming Systems of the Sahel: a review of strategies for increased productivity and sustainability. In: Livestock and sustainable nutrient cycling in mixed farming systems of sub-Saharan Africa. Volume 2: technical papers. Proceedings, Addis Ababa, Ethiopia, 22-26 November 1993, pp. 293-303.

Publisher's note Springer Nature remains neutral with regard to jurisdictional claims in published maps and institutional affiliations. 